\title{
PERIUNGUAL POROMA OF THUMB
}

\author{
Radharaman Panda ${ }^{1}$
}

${ }_{1}^{1}$ Assistant Professor, Department of General Surgery, Late Sri Lakhiram Agrawal Memorial Government Medical College.

ABSTRACT

\section{BACKGROUND}

Poroma is a benign cuticular appendageal tumour, first described by Goldman and Pinkus $1956 .{ }^{1}$ Its sites of occurrences are sole, ${ }^{2}$ scalp, ${ }^{3}$ chest and neck ${ }^{4}$ and leg. ${ }^{5}$ It is very rarely seen in the periungual and subungual region of thumb. A 42 -year-old male patient presented with a painless, red colour nodule of 9 years' duration on the thumb which was diagnosed clinically to be a case of angioma. On excision and histopathological study, it was diagnosed as a case of periungual eccrine poroma. Due to its rare occurrence in such a site, I am reporting it.

\section{KEYWORDS}

Periungual, Eccrine, Poroma.

HOW TO CITE THIS ARTICLE: Panda R. Periungual poroma of thumb. J. Evolution Med. Dent. Sci. 2017;6(34):2858-2859, D0I: 10.14260/Jemds/2017/615

\section{BACKGROUND \\ CLINICAL HISTORY}

A 42-year-old male patient presented in the outpatient department with a painless swelling over the tip of the right thumb from past 9 years. On examination, the swelling was red, nontender, firm in consistency of size $1 \mathrm{~cm} \times 0.5 \mathrm{~cm}$, arising from the tip of the right thumb surrounding the nail plate and extended below the nail plate [Fig-1]. The general condition of the patient, complete blood count, haemogram and x-ray of the right thumb were normal. The patient did not give any history of trauma, infection or radiation exposure of the right hand prior to this occurrence.

A clinical provisional diagnosis of angioma was done and the patient was posted for surgery. Under right supraclavicular brachial block and tourniquet application on the thumb, the tumour was excised in toto along with the nail plate, with $2 \mathrm{~mm}$ of tumour free margin. A split thickness skin graft was taken from the right arm and was applied over the secondary defect. The excised tissue was sent for histopathological study. The patient was discharged on the same day of operation and on the ninth post-operative day the patient was called for removal of stitches. There was complete graft acceptance with healthy operated area.

The patient came for followup after 1 year [Fig-2]. It was seen that the nail of the operated site was normal with acceptable residual defect of nail. Histology of excised tissue shows stratified squamous epithelium over fibrocollagenous stroma, cords and wide column of basaloid cell extending into the dermal stroma from overlying epithelium, rich vascularity within stroma in between these cords, confirming the diagnosis of periungual eccrine poroma.

Financial or Other, Competing Interest: None.

Submission 22-03-2017, Peer Review 15-04-2017,

Acceptance 21-04-2017, Published 27-04-2017.

Corresponding Author:

Dr. Radharaman Panda,

Department of Surgery,

Pradhanpara, Budharaja,

Sambalpur,

Odisha-768004

India.

E-mail: drradharaman@yahoo.co.in

DOI: $10.14260 /$ jemds $/ 2017 / 615$

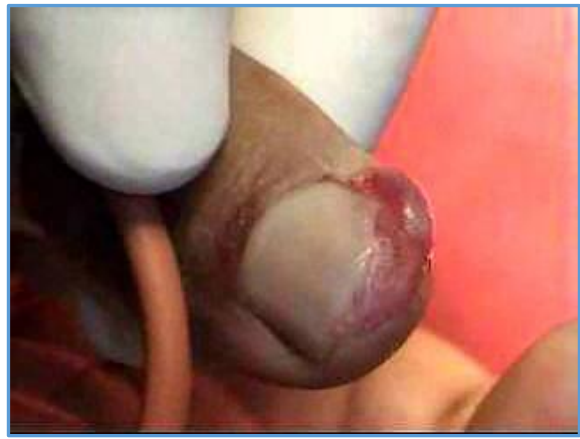

Figure 1. Tumour Surrounded to Nail, below Thumb

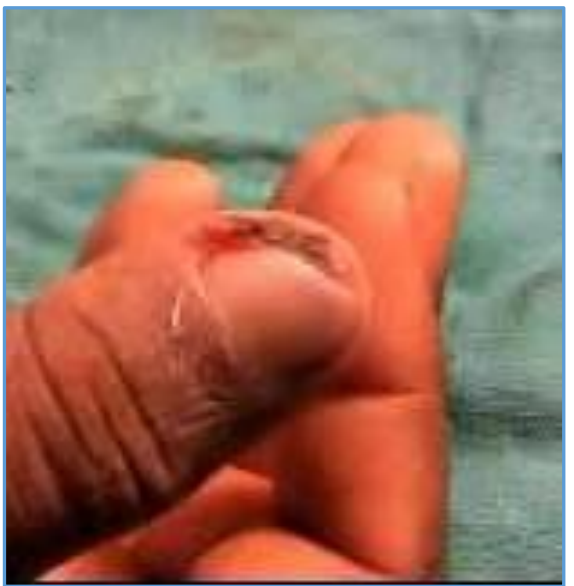

Figure 2. Post-operative

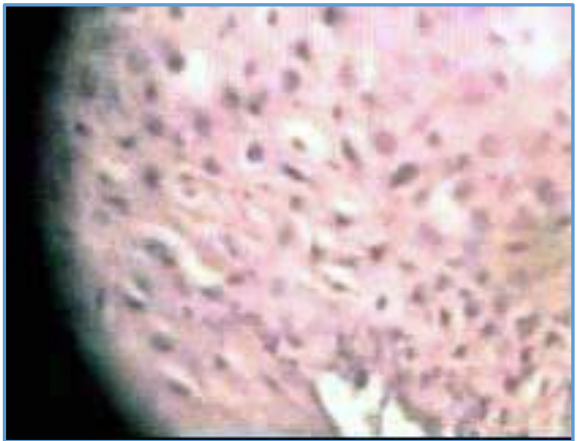

Figure 3. Histology of Poroma, Cells Contain Glycogen 


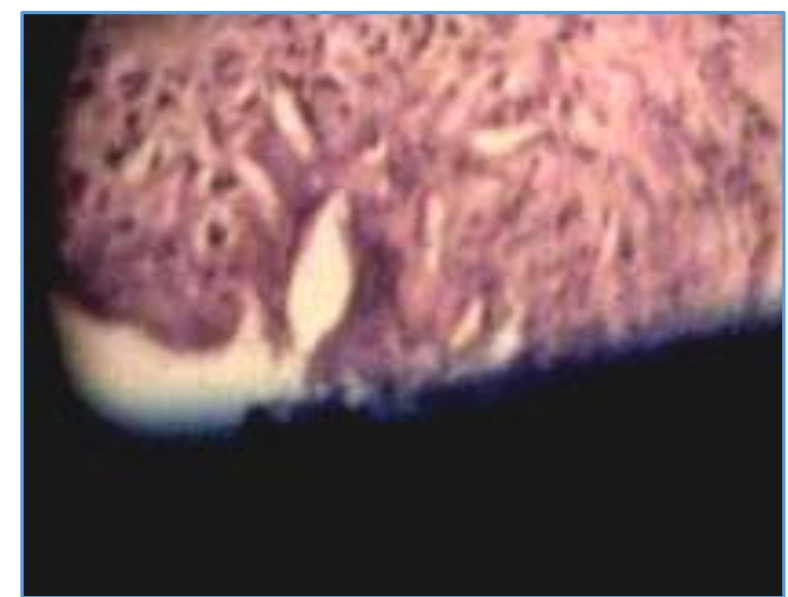

Figure 4. Histology of Poroma, Narrow Ductal Lumina

\section{DISCUSSION}

Eccrine poroma of sweat gland arises within the lower portion of the epidermis and it proliferates downward into the dermis, consisting of broad anastomosing bands. ${ }^{6}$ The tumour cells contain significant amount of glycogen [Fig-3]. In most of the cases, narrow ductal lumina [Fig-4] or cystic spaces may be found. Eccrine poroma is sometimes located entirely within the epidermis or within the dermis.

The dermal one is referred as dermal ductal tumour. The differential diagnosis may be pyogenic granuloma, glomangioma, haemangioma, pigmented basal cell carcinoma, pigmented nevus or melanoma.

\section{REFERENCES}

[1] Goldman P, Pinkus H, Rogin JR. Eccrine poroma: tumour existing feature of the epidermal sweat duct unit. AMA Arch Dermatol 1956;74(5):511-21.

[2] Hyman AB, Brownstein MH. Eccrine poroma. An analysis of 45 new cases. Dermatologica 1969;138(1):29-38.

[3] Cherif F, Dhaoui A, Kort R, et al. Eccrine poroma of the scalp: a study of three cases. Tunis Med 2006;84(6):391-3.

[4] Pennys NS, Ackerman AB, Indgin SN, et al. Eccrine poroma. Br J Dermatol 1970;82:613-5.

[5] Desai C. An uncommon presentation of eccrine poroma. Indian Dermatol Online J 2016;7(6):546-547.

[6] Lever WF, Gundula SL. Histopathology of the skin. Philadelphia: JB Lippincott 1990:611-2. 